\title{
Assessment of phytoremediation potencial of Allium cepa L. in raw sewage treatment
}

\author{
A. S. Bertan (D), F. P. Baumbach $^{a}$, (D), I. B. Tonial ${ }^{b}$ (D), T. S. Pokrywiecki (D) and E. Düsman ${ }^{b *}$ (D) \\ ${ }^{a}$ Departamento de Engenharia Química, Universidade Tecnológica Federal do Paraná - UTFPR, Linha Santa Bárbara, s/n, \\ CEP 85601-970, Francisco Beltrão, PR, Brasil \\ bDepartamento de Química e Biologia, Universidade Tecnológica Federal do Paraná - UTFPR, Linha Santa Bárbara, s/n, \\ CEP 85601-970, Francisco Beltrão, PR, Brasil \\ 'Departamento de Engenharia Ambiental, Universidade Tecnológica Federal do Paraná - UTFPR, Linha Santa Bárbara, \\ s/n, CEP 85601-970, Francisco Beltrão, PR, Brasil \\ *e-mail: edusman@utfpr.edu.br
}

Received: September 19, 2018 - Accepted: January 02, 2019 - Distributed: May 31, 2020

(With 2 figures)

\begin{abstract}
Whereas the effects of the substances found in domestic sewage on live organisms is important to evaluate the use of plants to remove pollutants from the environment. The objective of this study was to assess the phytoremediation activity of Allium cepa L. (onion) roots exposed to raw sewage, as well as the acute toxic activity of this effluent for the bioindicators A. cepa, through a cytotoxicity test, and Artemia salina L., through a mortality/immobility test. The physicochemical assessments of the sewage were conducted in two scenarios: immediately after collection and after being in contact with onion roots (phytoremediation) for 24 hours. The physicochemical data indicate there was a reduction in nitrogen and phosphorus levels and in biochemical oxygen demand in sewage treated. The results from the cytotoxicity test with $A$. cepa indicated a reduction in the mitotic cell divisions of the onions treated with the raw sewage. The mortality/immobility test with $A$. salina indicated that the concentrations with 50 and $100 \%$ of raw sewage induced the mortality of the nauplii. Thus, the data suggest new studies that seek greater efficiency, efficacy and viability of onion phytoremediation.
\end{abstract}

Keywords: Allium cepa L., Artemia salina L., bioindicators, mortality, phytoremediation.

\section{Avaliação do potencial de fitorremediação da Allium cepa L. no tratamento do esgoto bruto}

\section{Resumo}

Considerando os efeitos das substâncias encontradas no esgoto doméstico em organismos vivos, é importante avaliar o uso de plantas para remover poluentes do meio ambiente. O objetivo deste trabalho foi avaliar a atividade de fitorremediação de raízes de Allium cepa L. (cebola) expostas ao esgoto bruto, bem como a atividade tóxica aguda desse efluente para os bioindicadores $A$. cepa, através de um teste de citotoxicidade, e Artemia salina L., através de um teste de mortalidade/imobilidade. As avaliações físico-químicas do esgoto foram realizadas em dois cenários: imediatamente após a coleta e após contato com raízes de cebola (fitorremediação) por 24 horas. Os dados físico-químicos indicam que houve redução nos níveis de nitrogênio e fósforo e na demanda bioquímica de oxigênio no esgoto tratado. Os resultados do teste de citotoxicidade com $A$. cepa indicaram uma redução nas divisões celulares mitóticas das cebolas tratadas com o esgoto bruto. $\mathrm{O}$ teste de mortalidade/imobilidade com A. salina indicou que as concentrações com 50 e $100 \%$ de esgoto bruto induziram a mortalidade dos náuplios. Assim, os dados sugerem novos estudos que busquem maior eficiência, eficácia e viabilidade de fitorremediação das cebolas.

Palavras-chave: Allium cepa L., Artemia salina L., bioindicadores, mortalidade, fitorremediação.

\section{Introduction}

The human species has significantly raised the concentration of xenobiotic substances in the environment, as a result of urban, domestic and industrial activities (Kunz et al., 2002). Many of these molecules, when spilled into an aquatic environment, harm the entire ecosystem and food chain and, although some rivers have a capacity for self-purification, it is known that many do not achieve this effect (Roveri, 2012). 
In this sense, sewage and its by-products, such as sewage sludge, may have high concentrations of potentially toxic elements representing a potential risk for the whole ecosystem (Abreu-Junior et al., 2019). According to Instituto Trata Brasil (2018), only about $51.92 \%$ of the Brazilian population has access to sewage collection, of which only $44.92 \%$ receive treatment. For this reason, it is important to assess the effects of environmental pollution, especially that generated by sewage, on organisms, specifically with regard to toxicology. The Allium cepa L. has been widely used as a bioindicator organism in experiments (Egito et al., 2007; Abreu-Junior et al., 2019), as its roots grow quickly and it is quite sensitive to environmental changes, making its results comparable to those obtained with prokaryotes, lymphocytes test systems and ames test (Cabuga et al., 2017; Klauck et al., 2017; Fatma et al., 2018). The Artemia salina L. is also an organism widely used to assess toxicity levels, since it is highly sensitive and provides biological responses in a relatively short time (Villarroel et al., 2003), besides having a good correlation with in vivo acute oral toxicity tests (Silva et al., 2010).

Bioremediation is a process in which live organisms, like fungi, bacteria and plants, are used to reduce the pollution levels of the environment. The enzymatic and metabolic processes of these organisms are capable to remove certain components from a polluted environment, so reducing its altered parameters (Eruke and Udoh, 2015).

Phytoremediation is a decontamination process in which plants are used to remove pollutants from the environment or to transform the pollutants into substances that are less dangerous for the living beings. Phytoremediation provides huge environmental benefits at a cost lower than physicochemical methods. This area of study has gained momentum in the last ten years, with the discovery of the biotransformation capacity that plant roots have over exogenous organic molecules (Andreazza et al., 2015; Baracuhy et al., 2015; Silva et al., 2015; Freitas et al., 2018).

Correlation between the increase of organic load and the stimulation of cell divisions of meristematic cells from the roots of $A$. cepa has already been established (Düsman et al., 2014), however, no study has verified the phytoremediation potential of this organism, especially with regard to the consumption of nitrogen and phosphorus, or the decrease of chemical and biochemical demand of oxygen when this bioindicator is exposed to water with elevated organic load, such as sewage.

Thus, this study aimed to assess phytoremediation activity of $A$. серa, after 24 hours of contact with raw sewage collected from Sanepar, as well as the toxic effects of this effluent on the A. cepa and A. salina bioindicators.

\section{Materials and Methods}

\subsection{Sampling}

The raw sewage was provided by SANEPAR ("Companhia de Saneamento do Paraná"), the sanitary sewer service company of the state of Paraná, Brazil, in city of Francisco Beltrão/Paraná, where around 20,768 habitants are attended by this company. The collection, as well as its preservation, followed the methodology described in Standard Methods (American Public Health Association et al., 2012).

\subsection{Physicochemical analyses}

The physicochemical parameters analyzed were: $\mathrm{pH}$ and temperature were evaluated using a microprocessed $\mathrm{pH}$ meter DLA(Del Lab.), the chemical oxygen demand (COD) was performed through the closed reflux colorimetric method, the biochemical oxygen demand $\left(\mathrm{DBO}_{5}\right)$ using the dilution incubation method, based on the difference of dissolved oxygen concentration in the five day period and temperature of $20^{\circ} \mathrm{C}$, the dissolved oxygen was measured with the HI 98186 (Hanna), total coliforms using the multi-tube fermentation method, for total nitrogen the macro Kjeldahl method and the phosphor was measured using the digestion method, according to the methodologies recommended in Standard Methods (American Public Health Association et al., 2012).

Physicochemical analyses were conducted in triplicate with one sample of the sewage, immediately after collection (raw sewage), and with one sample after 24 hours of contact with onion roots (phytoremediation process). Statistical analysis was conducted through the application of analysis of variance (ANOVA) and Mann-Whitney U-test for mean comparison $(\alpha=0.05)$ of the three replicates $(n=3)$.

\subsection{Phytoremediation}

Onion bulbs, weighing 70 grams per unit, were accommodated for rooting in plastic disposable cups with filtered water at room temperature in an aerated and dark space. Once the onion roots were about $2 \mathrm{~cm}$ long, ten onion bulbs were selected and placed in contact with $1,500 \mathrm{~mL}$ of the raw sewage provided by SANEPAR $(150 \mathrm{~mL}$ of sewage/bulb) for 24 hours. The goal was verifying the quantity of organic load that the roots could absorb in this period and, therefore, their capacity to promote the phytoremediation of the effluent.

\subsection{Cytotoxicity for the A. cepa bioindicator}

The cytotoxicity test with $A$. cepa (pear onion) was conducted with meristematic cells of onion roots, which were prepared through the Feulgen reaction and dyed with Schiff reagent (Fiskesjö, 1985).

Overall, the onion bulbs were left to root in disposable plastic cups with filtered water at room temperature and in an aerated and dark place. After obtaining the roots, the bulbs were separated into groups of 5 bulbs, for the negative control and the sewage treatment.

Before each treatment, two roots (approximately $2 \mathrm{~cm}$ long) were collected from each bulb and placed in jars with a methanol and acetic acid fixative solution (3:1), for at least 24 hours in the refrigerator, to serve as the control for the bulbs ( 0 hours). Next, these bulbs were placed in the samples of sewage provided by Sanepar, for 24 hours. After the treatment period, once again two roots were removed from each onion and submitted to fixation for 24 hours. The remaining roots were washed and bulbs were placed again in filtered water for 24 hours, where 
they recovered from the potential damage caused by the exposure to sewage. Two roots were collected and fixated for 48 hours. In the negative control group was follow the same methodology, but the onions always maintaining in filtered water.

The roots were then removed from the refrigerator and washed twice with water, remaining in hydrochloric acid 1 mol.L-1 at $60{ }^{\circ} \mathrm{C}$ for 10 minutes; then washed again and exposed to the Schiff reagent for 45 minutes in the dark. Slides were prepared with the meristematic region of the roots, identified by the color acquired by the contact with the Schiff reagent. This process involved the maceration of the cells with the acetic-orceindye and crushing the material under the cover slip. The slides were analyzed under a light microscope, using a $40 \mathrm{X}$ objective lens, and 1,000 cells were counted per bulb, totaling 5,000 cells for each sampling time (control, treatment and recovery) for the negative control group and for the group treated with raw sewage. The cells were identified according to the phase of mitotic cell division: interphase, prophase, metaphase, anaphase and telophase. The following Formula (1) was used to calculate the percentage of mitotic index:

$\mathrm{MI} \%=\frac{\text { Number of cells in division }}{\text { total number of cells analyzed }} \times 100$

The statistical analysis was carried out using the chi-squared test $(\alpha=0.05 ; n=5)$.

\subsection{Toxicity for the A. salina bioindicator}

The method proposed by Guerra (2001), with some adjustments was applied for the immobility/mortality test carried out with the $A$. salina bioindicator. After hatching, the microcrustaceans were distributed in four test tubes (10 organisms for each tube) containing $2 \mathrm{~mL}$ of raw sewage, diluted into $100,50,25,12.5,6.2$ and $3.1 \%$ concentrations of saline solutions (30 $\mathrm{g}$ sea salt/L of distilled water). In the negative control, the nauplii were placed in a $2 \mathrm{~mL}$ saline solution.

After 24 hours, dead and immobile nauplii were counted. The statistical analysis was carried out using ANOVa and Dunnett's method $(\alpha=0.05)$ by the mean number of dead organisms in the four replicates $(n=4)$.

\section{Results and Discussion}

The data of the physical-chemical analyzes of the raw sewage (Table 1) show that sewage from different cities can contain different pollutant compositions and quantities. Grisolia et al. (2005), for example, conducted physicochemical tests on a raw sewage effluent, finding $\mathrm{BOD}_{5}$ and COD data similar to those from this study; however, the total nitrogen and phosphorus were, respectively, 1.62 and 16.56 times higher than those of the current study (nitrogen $=18.11 \pm 4.29 \mathrm{mg} / \mathrm{L}$, phosphorus $=0.32 \pm 0.17 \mathrm{mg} / \mathrm{L}$ ). In the studies by Marguti et al. (2008) and Rodrigues et al. (2009), the phosphorus and nitrogen data were also higher than those of this study. Moreover, when comparing the COD and $\mathrm{BOD}_{5}$ data obtained by Passamani et al. (2014), the $\mathrm{BOD}_{5}$ values were similar, but the $\mathrm{COD}$ values were 1.48 times higher.

The assay of phytoremediation with $A$. cepa revealed that the physicochemical parameters assessed on sewage treated with phytoremediation were not statistically different $(p>0.05)$ from those of raw sewage (Table 1). And, there was no decrease in the number of coliform bacteria resulting from the applied treatment. Baracuhy et al. (2015) were able to reduce the number of total coliform bacteria in graywater through phytoremediation with the vegetable grass purple.

Despite the absence of significant difference, the data show that there was a $32 \%, 18 \%$ and $11.8 \%$ of reduction in the concentrations of nitrogen, phosphorus and $\mathrm{BOD}_{5}$, respectively. The comparison of the results of this study with those obtained by Quege et al. (2013), in a study carried out with bamboo, shows that bamboo plants are more efficient in reducing the levels of these parameters after 2.3 days of sanitary sewage treatment, since they removed $98.3 \%$ of $\mathrm{BOD}_{5}, 97.1 \%$ of $\mathrm{COD}, 98.4 \%$ of phosphate and $98.3 \%$ of ammoniacal nitrogen. Other studies also show that different plants and treatment times result in different efficiencies of phytoremediation. Benvenuti et al. (2018), for example, shown that macrophytes Typha domingensis Pers., applied to the treatment of raw sewage in a municipal sewage treatment plant, during 12 months, reduced $56 \%$ of $\mathrm{BOD}_{5}, 55 \%$ of $\mathrm{COD}, 78 \%$ of total suspended solids, $37 \%$ of total phosphorus and $41 \%$ of nitrogen.

Table 1. Physicochemical parameters of raw sewage and sewage treated with phytoremediation.

\begin{tabular}{lccc}
\hline \multicolumn{1}{c}{ Parameters } & Raw Sewage & Treated Sewage & Alteration (\%) \\
\hline pH & $6.45 \pm 0.30 \mathrm{a}$ & $6.78 \pm 1.00 \mathrm{a}$ & 5 \\
BOD $(\mathbf{m g} / \mathbf{L})$ & $113.95 \pm 56.07 \mathrm{a}$ & $100.42 \pm 31.59 \mathrm{a}$ & 11.8 \\
COD (mg/L) & $355 \pm 1.00 \mathrm{a}$ & $363.00 \pm 1.00 \mathrm{a}$ & 2 \\
Nitrogen (mg/L) & $18.21 \pm 4.29 \mathrm{a}$ & $12.38 \pm 0.00 \mathrm{a}$ & 32 \\
Phosphorus (mg/L) & $0.32 \pm 0.17 \mathrm{a}$ & $0.26 \pm 0.16 \mathrm{a}$ & 18 \\
DO (mg/L) & $1.61 \pm 0.01 \mathrm{a}$ & $1.59 \pm 0.01 \mathrm{a}$ & 1.2 \\
Total Coliforms (MPN) & $23.00 \pm 1.00 \mathrm{a}$ & $23.00 \pm 1.00 \mathrm{a}$ & - \\
\hline
\end{tabular}

pH: Potential of Hydrogen; BOD: Biochemical Oxygen Demand; COD: Chemical Oxygen Demand; DO: Dissolved Oxygen; MPN: Most Probable Number. Means followed by the same letter in each line do not differ statistically from each other, according to Mann-Whitney U-test at 5\%. 
However, the nitrogen reduction value of the raw sewage from the work by Benvenuti et al. (2018) (41\%) was similar to the present study (32\%). Probably this nutrient was absorbed by the roots of onion for its growth and development. This finding corroborates the study conducted by Gomes et al. (2007), an increase in the level of nitrogen was found among the corn leaves due to the quantity of sewage sludge fertilizing the soil. It also agrees the conclusions of Figueiredo and Grassi Filho (2007), who found that substituting the nitrogen of chemical fertilizers by sewage sludge resulted in a significant increase in the production of sunflower grains, oil and dry matter.

Nevertheless, the data of cytotoxicity test carried out with onion roots in the present study (Figure 1) show that the treatment of the bulbs with the raw sewage, after 24 hours, were cytotoxic to $A$. cepa because statistically decreased the mitotic index (MI: 1.2\%), when compared to the cell division index of the negative control for the same time (24 hours) (MI: $2.5 \%$ ). The cytotoxicity, by the reduction in the mitotic index of $A$. cepa, was also confirmed by Mazzeo et al. (2015), with raw sewage sludge collected from the city of Rio Claro, in the state of São Paulo, Brazil, after mitigation tests, and by Srivastava et al. (2005), with an aqueous extract of the sewage sludge collected from a city in India. Sommaggio et al. (2018 a,b) also demonstrated the cytotoxicity of sewage sludge by $A$. cepa and HepG2 cells, respectively, before and after being bioremediated.

As shown by Mazzeo et al. (2015), raw sewage from Francisco Beltrão probably contains, in addition to a high organic load, other substances capable of inhibiting cellular division, since, this type of wastewater is the result of complex mixtures of organic and inorganic components, in addition to heavy metals that influence the mitotic index and the occurrence of chromosome anomalies (Mazzeo et al., 2015; Ozaki et al., 2017). The fact that some metals are engulfed by cells during the process known as phagocytosis or pinocytosis, causing molecular damage to

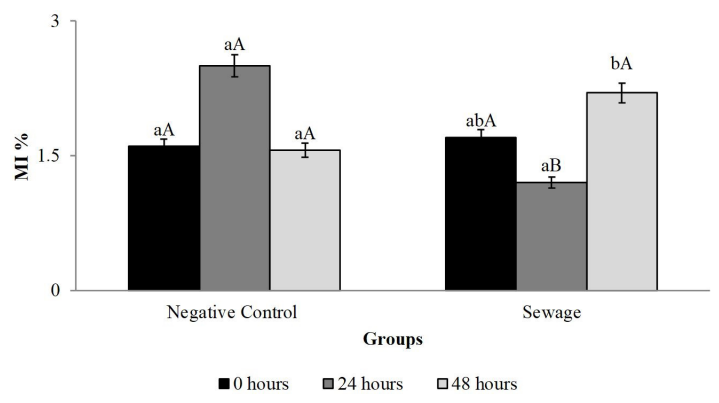

Figure 1. Mitotic Indices (MI) of the negative control group and the group treated with sewage, for the collection times of 0,24 and 48 hours. Means followed by the same lowercase letter do not differ from each other in the comparison between the different exposure times of each control or treated group, and means followed by the same capital letter do not differ from each other in the comparison between the negative control and sewage for each exposure time, by the Chi-Square test $(\alpha=0.05)$.
DNA, must also be taken into consideration (Matsumoto and Marin-Morales, 2004). In this sense, Kumwimba et al. (2017), studying the phytoremediation of domestic sewage with different plants, confirmed accumulation of aluminum, cadmium, arsenic, lead, chromium, iron and nickel in their roots. Silva et al. (2015) showed that the levels of copper applied to the soil decreased the quality of seedlings and growth of Apuleia leiocarpa.

However, the onion roots used in this study were able to recover after 24 hours of recovering in filtered water (time: 48 hours), resulting in a statistically significant increase in the mitotic index of the collection time, from 24 to 48 hours.

In addition, the mortality/immobility test (Figure 2) with the $A$. salina bioindicator revealed that the sewage concentrations of $50 \%$ and $100 \%$ caused the death of the nauplii after 24 hours of treatment, when compared to the negative control. The toxic effect was dose-dependent since, with the increase in the sewage concentration, there was a higher level of mortality among the microcrustaceans, reaching basically full mortality in the $100 \%$ sewage concentration $(9.75 \pm 0.5$ dead organisms).

Similar results were found by Fels et al. (2016), in which the aqueous extract of sewage sludge caused an $80 \%$ mortality rate of $A$. salina larvae. In addition, other study has shown the toxicity of metals, like cadmium and chrome, for the nauplii of this microcrustacean (Hadjispyrou et al., 2001). Rosenthal and Alderdice (1976) have suggested that a pollutant can inhibit the movement of nauplii, causing an accumulation of the incubation enzyme around their heads, which results in premature hatching and death.

These data are worrisome, since many types of cancer found in humans are caused by the agents present in the water of rivers (Egito et al., 2007). Research has shown that rivers, especially in Europe, Asia and South America, have contaminants that are responsible for the appearance of various cases of cancer. Even if raw sewage is treated, many components are not broken down and remain in the water that will eventually be consumed by the population (Grisolia et al., 2005).

Although these results, new studies should be conducted seeking higher phytoremediation efficiency from onions or others plants, increasing the period of exposure of the

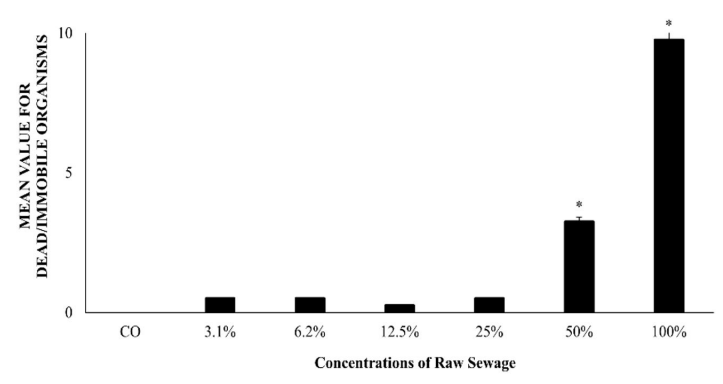

Figure 2. Mean value for dead/immobile organisms for negative control $(\mathrm{CO})$ and different concentrations of raw sewage. *Statistically different result for the negative control. 
sewage to onion roots, reduce the volume of sewage per bulb, assess heavy metals concentration in the sample and verify if they are correlated with cytotoxicity, analyzing the accumulation of compounds such as nitrogen, phosphorus and some metals to verify the bioaccumulation capacity of the plants or if what has been absorbed is degraded in the plant metabolism and, finally, verifying the cytotoxicity and toxicity of the raw and treated sewage for the bioindicators A. cepa and A. salina.

\section{Acknowledgements}

To the Federal Technological University of Paraná, Francisco Beltrão, Paraná, Brazil campus and to the laboratory of Mutagenesis and Environmental Monitoring of the State University of Maringá - UEM.

\section{References}

ABREU-JUNIOR, C.H., BROSSI, M.J.L., MONTEIRO, R.T., CARDOSO, P.H.S., MANDU, T.S., NOGUEIRA, T.A.R., GANGA, A., FILZMOSER, P., OLIVEIRA, F.C., FIRME, L.P., HE, Z. and CAPRA, G.F., 2019. Effects of sewage sludge application on unfertile tropical soils evaluated by multiple approaches: a field experiment in a commercial Eucalyptus plantation. The Science of the Total Environment, vol. 655, pp. 1457-1467. http://dx.doi. org/10.1016/j.scitotenv.2018.11.334. PMid:30577137.

AMERICAN PUBLIC HEALTH ASSOCIATION - APHA, AMERICAN WATER WORKS ASSOCIATION - AWWA, WATER ENVIRONMENT FEDERATION - WEF, 2012. Standard methods for the examination of water and wastewater. 22nd ed. Canada: APHA, AWWA, WEF.

ANDREAZZA, R., BORTOLON, L., PIENIZ, S., BENTO, F.M. and CAMARGO, F.A.O., 2015. Evaluation of two Brazilian indigenous plants for phytostabilization and phytoremediation of copper-contaminated soils. Brazilian Journal of Biology $=$ Revista Brasileira de Biologia, vol. 75, no. 4, pp. 868-877. http://dx.doi. org/10.1590/1519-6984.01914. PMid:26675903.

BARACUHY, V.S., PEREIRA, J.P.G., FERREIRA, A.C., SILVA, V.F. and NICOLA, S., 2015. Eficiência na remoção de coliformes em águas cinza através da fitorremediação. Revista Verde de Agroecologia e Desenvolvimento Sustentável, vol. 10, no. 1, pp. 57-61. http://dx.doi.org/10.18378/rvads.v10i1.3330.

BENVENUTI, T., HAMERSKI, F., GIACOBBO, A., BERNARDES, A.M., ZOPPAS-FERREIRA, J. and RODRIGUES, M.A.S., 2018. Constructed floating wetland for the treatment of domestic sewage: a real-scale study. Journal of Environmental Chemical Engineering, vol. 6, no. 5, pp. 5706-5711. http://dx.doi. org/10.1016/j.jece.2018.08.067.

CABUGA, C.C., ABELADA, J.J.Z., APOSTADO, R.R.Q., HERNANDO, B.J.H., LADOR, J.E.C., OBENZA, O.L.P., PRESILDA, C.J.R. and HAVANA, H.C., 2017. Allium cepa test: an evaluation of genotoxicity. Proceedings of the International Academy of Ecology and Environmental Sciences, vol. 7, no. 1, pp. 12-19.

DÜSMAN, E., LUZZA, M., SAVEGNAGO, L., LAUXEN, D., VICENTINI, V.E., TONIAL, I.B, 2014. Allium cepa L. as a bioindicator to measure cytotoxicity of surface water of the Quatorze River, located in Francisco Beltrão, Paraná, Brazil. Environmental Monitoring and Assessment, vol. 186, no. 3, pp. 1793-1800. http://dx.doi.org/10.1007/s10661-013-3493-8. PMid:24162370.

EGITO, L.C.M., MEDEIROS, M.G., MEDEIROS, S.R.B. and AGNEZ-LIMA, L.F., 2007. Cytotoxic and genotoxic potencial of surface water from the Pitimbu river, northeastern/RN Brasil. Genetics and Molecular Biology, vol. 30, no. 2, pp. 435-441. http://dx.doi.org/10.1590/S1415-47572007000300023.

ERUKE, O.S. and UDOH, A.J., 2015. Potentials for biosurfactant enhanced bioremediation of hydrocarbon contaminated soil and water - a review. Advances in Research, vol. 4, no. 1, pp. 1-14. http://dx.doi.org/10.9734/AIR/2015/11933.

FATMA, F., VERMA, S., KAMAL, A. and SRIVASTAVA, A., 2018. Monitoring of morphotoxic, cytotoxic and genotoxic potential of mancozeb using Allium assay. Chemosphere, vol. 195, pp. 864-870. http://dx.doi.org/10.1016/j.chemosphere.2017.12.052. PMid:29273330

FELS, L.E., HAFIDI, M. and OUHDOUCH, Y., 2016. Artemia salina as a new index for assessment acute cytotoxicity during co-composting of sewage sludge and lignocellulose waste. Waste Management (New York, N.Y.), vol. 50, pp. 194-200. http://dx.doi. org/10.1016/j.wasman.2016.02.002. PMid:26868843.

FIGUEIREDO, T. and GRASSI FILHO, L.H.G., 2007. Níveis de lodo de esgoto na produtividade do girassol. Revista de la Ciencia del Suelo y Nutrición Vegetal, vol. 7, no. 3, pp. 16-25. http://dx.doi.org/10.4067/S0718-27912007000300002.

FISKESJÖ, G., 1985. The Allium test as a standard in environmental monitoring. Hereditas, vol. 102, no. 1, pp. 99-112. http://dx.doi. org/10.1111/j.1601-5223.1985.tb00471.x. PMid:3988545.

FREITAS, F., LUNARDI, S., SOUZA, L.B., VON DER OSTEN, J.S.C., ARRUDA, R., ANDRADE, R.L.T. and BATTIROLA, L.D., 2018. Accumulation of copper by the aquatic macrophyte Salvinia biloba Raddi (Salviniaceae). Brazilian Journal of Biology = Revista Brasileira de Biologia, vol. 78, no. 1, pp. 133-139. http://dx.doi.org/10.1590/1519-6984.166377. PMid:28699967.

GOMES, S.B.V., NASCIMENTO, C.W.A. and BIONDI, C.M., 2007. Produtividade e composição mineral de plantas de milho em solo adubado com lodo de esgoto. Revista Brasileira de Engenharia Agrícola e Ambiental, vol. 11, no. 5, pp. 459-465. http://dx.doi.org/10.1590/S1415-43662007000500002.

GRISOLIA, C.K., OLIVEIRA, A.B.B., BONFIM, H. and KLAUTAU-GUIMARÃES, M.N., 2005. Genotoxicity evaluation of domestic sewage in a municipal wastewater treatment plant. Genetics and Molecular Biology, vol. 28, no. 2, pp. 334-338. http://dx.doi.org/10.1590/S1415-47572005000200026.

GUERRA, R., 2001. Ecotoxicological and chemical evaluation of phenolic compounds in industrial effluents. Chemosphere, vol. 44, no. 8, pp. 1737-1747. http://dx.doi.org/10.1016/S00456535(00)00562-2. PMid:11534905.

HADJISPYROU, S., KUNGOLOS, A. and ANAGNOSTOPOULOS, A., 2001. Toxicity, bioaccumulation, and interactive effects of organotin, cadmium, and chromium on Artemia franciscana. Ecotoxicology and Environmental Safety, vol. 49, no. 2, pp. 179186. http://dx.doi.org/10.1006/eesa.2001.2059. PMid:11386732.

INSTITUTO TRATA BRASIL - ITB, 2018 [viewed 5 December 2018]. Saneamento: principais estatísticas no Brasil [online]. São Paulo: ITB. Available from: http://www.tratabrasil.org.br/ saneamento/principais-estatisticas/no-brasil/esgoto

KLAUCK, C.R., GIACOBBO, A., OLIVEIRA, E.D.L., SILVA, L.B. and RODRIGUES, M.A.S.., 2017. Evaluation of acute toxicity, cytotoxicity and genotoxicity of landfill leachate 
treated by biological lagoon and advanced oxidation processes. Environmental Chemical Engineering, vol. 5, no. 6, pp. 61886193. http://dx.doi.org/10.1016/j.jece.2017.11.058.

KUMWIMBA, M.N., ZHU, B., SUANON, F., MUYEMBE, D.K. and DZAKPASU, M., 2017. Long-term impact of primary domestic sewage on metal/loid accumulation in drainage ditch sediments, plants and water: implications for phytoremediation and restoration. The Science of the Total Environment, vol. 581-582, pp. 773-781. http://dx.doi.org/10.1016/j.scitotenv.2017.01.007. PMid:28073642.

KUNZ, A., PERALTA-ZAMORA, P., MORAES, S.G. and DURÁN, N., 2002. Novas tendências no tratamento de efluentes têxteis. Quimica Nova, vol. 25, no. 1, pp. 78-82. http://dx.doi. org/10.1590/S0100-40422002000100014.

MARGUTI, A.L., FERREIRA FILHO, S.S. and PIVELI, R.P., 2008. Otimização de processos físico-químicos na remoção de fósforo de esgotos sanitários por processos de precipitação química com cloreto férrico. Engenharia Sanitaria e Ambiental, vol. 13 , no. 4 , pp. 395-404. http://dx.doi.org/10.1590/S141341522008000400008

MATSUMOTO, S.T. and MARIN-MORALES, M.A., 2004. Mutagenic potential of the water of a river that receives tannery effuent using the Allium cepa test system. Revista Cytologia, vol. 69, no. 4, pp. 399-408. http://dx.doi.org/10.1508/cytologia.69.399.

MAZZEO, D.E.C., FERNANDES, T.C.C., LEVY, C.E., FONTANETTI, C.S. and MARIN-MORALES, M.A., 2015. Monitoring the natural attenuation of a sewage sludge toxicity using the Allium cepa test. Ecological Indicators, vol. 56, pp. 60-69. http://dx.doi.org/10.1016/j.ecolind.2015.03.026.

OZAKI, N., NAKAZATO, A., NAKASHIMA, K., KINDAICHI, T. and OHASHI, A., 2017. Loading and removal of PAHs, fragrance compounds, triclosan and toxicity by composting process from sewage sludge. The Science of the Total Environment, vol. 605-606, pp. 860-866. http://dx.doi.org/10.1016/j.scitotenv.2017.06.165. PMid:28683430.

PASSAMANI, F.R.F., BOF, V.S., FIGUEIREDO, K.F., MOTTA, J.S., ROCHA, V.J.R. and GONÇALVEZ, R.F., 2014. Remoção de coliformes fecais e patógenos em um conjunto uasb-bf tratando esgoto sanitário. In: $20^{\circ}$ Congresso Brasileiro de Engenharia Sanitária e Ambiental, 1999, Rio de Janeiro. Rio de Janeiro: Associação Brasileira de Engenharia Sanitária e Ambiental ABES, pp. 394-401.

QUEGE, K.E., ALMEIDA, R.A. and UCKER, F.E., 2013. Utilização de plantas de bambu no tratamento de esgoto sanitário pelo sistema de alagados construídos. Revista Eletrônica em Gestão. Educação e Tecnologia Ambiental, vol. 10, no. 10, pp. 2069-2080. http://dx.doi.org/10.5902/223611707440.
RODRIGUES, L.N., NERY, A.R., FERNANDES, P.D. and BELTRÃO, N.E.M., 2009. Aplicação de água residuária de esgoto doméstico e seus impactos sobre a fertilidade do solo. Revista de Biologia e Ciências da Terra, vol. 9, no. 2, pp. 55-67.

ROSENTHAL, H. and ALDERDICE, D.F., 1976. Sublethal effects of environmental stressors, natural and pollutional, on marine fish eggs and larvae. Journal of the Fisheries Research Board of Canada, vol. 33, pp. 2047-2065.

ROVERI, V., 2012. Recursos eutrofizados: descrição de métodos preventivos e corretivos para sua recuperação. In: Simpósio Internacional de Ciências Integradas da UNAERP, 2012, Guarujá. Guarujá: UNAERP, pp. 1-10.

SILVA, L.L., HELDWEIN, C.G., REETZ, L.G.B., HÖRNER, R., MALLMANN, C.A. and HEINZMANN, B.M., 2010. Composição química, atividade antibacteriana in vitro e toxicidade em Artemia salina do óleo essencial das inflorescências de Ocimum gratissimum L., Lamiaceae. Revista Brasileira de Farmacognosia, vol. 20, no. 5, pp. 700-705. http://dx.doi.org/10.1590/S0102695X2010005000010.

SILVA, R.F., ANDREAZZA, R., DA ROS, C., DELLAI, A., JACQUES, R.J.S. and SCHEID, D., 2015. Growth of tropical tree species and absorption of copper in soil artificially contaminated. Brazilian Journal of Biology $=$ Revista Brasileira de Biologia, vol. 75, no. 4, suppl. 1, pp. S119-S125. http://dx.doi. org/10.1590/1519-6984.07114. PMid:26628229.

SOMMAGGIO, L.R.D., MAZZEO, D.E.C., PAMPLONASILVA, M.T. and MARIN-MORALES, M.A., 2018a. Evaluation of the potential agricultural use of biostimulated sewage sludge using mammalian cell culture assays. Chemosphere, vol. 199, pp. 10-15. http://dx.doi.org/10.1016/j.chemosphere.2018.01.144. PMid:29427809.

SOMMAGGIO, L.R.D., MAZZEO, D.E.C., SANT'ANNA, D.A.S., LEVY, C.E. and MARIN-MORALES, M.A., 2018b. Ecotoxicological and microbiological assessment of sewage sludge associated with sugarcane bagasse. Ecotoxicology and Environmental Safety, vol. 147, pp. 550-557. http://dx.doi. org/10.1016/j.ecoenv.2017.09.009. PMid:28918337.

SRIVASTAVA, R., KUMAR, D. and GUPTA, S.K., 2005. Bioremediation of municipal sludge by vermin technology and toxicity assessment by Allium cepa. Bioresource Technology, vol. 96, no. 17, pp. 1867-1871. http://dx.doi.org/10.1016/j. biortech.2005.01.029. PMid:15927461.

VILLARROEL, M.J., SANCHO, E., FERRANDO, M.D. and ANDREU, E., 2003. Acute, chronic and sublethal effects of the herbicide propanil on Daphnia magna. Chemosphere, vol. 53, no. 8, pp. 857-864. http://dx.doi.org/10.1016/S0045-6535(03)005460. PMid:14505707. 